\title{
Hymns, prayers and Bible stories: the role of religious literacy practices in children's literacy learning
}

\author{
Uta Papen \\ Literacy Research Centre \\ Department of Linguistics and English Language \\ County South \\ Lancaster University \\ Lancaster LA1 4YL \\ E-mail: u.papen@lancaster.ac.uk
}

\begin{abstract}
This paper examines the role of religious literacy practices such as hymns, prayers and Bible stories in the context of literacy teaching in primary schools in England. Drawing on data collected through a classroom ethnography of a year 1 class ( 5 and 6 year olds) conducted in a Catholic primary school in 2013 and 2014, I suggest that religious literacy practices contribute to children's literacy learning in various ways. They focus children's attention on a text's meaning, not on decoding, as other literacy lessons do. They do not privilege rational thinking but afford more emotional and bodily experiences of meaning making. These practices also offer opportunities for collaborative engagements with literacy, supporting learning through participation. My findings suggest that educators, researchers and policymakers should pay greater attention to the range of literacy practices children engage with and how they contribute to their literacy learning.
\end{abstract}

\section{Key words}

Literacy practices, classroom ethnography, Catholic religion,religious literacies, literacy learning primary school

\section{Introduction}

This paper deals with the role of (Christian) religious literacy practices such as hymns, prayers and Bible stories in the context of literacy learning in a Catholic primary school in the north of England. My interest in understanding religious practices as opportunities for literacy learning developed over the course of a one-year long classroom ethnography, taking place in 2013-2014. My original motivation for this study had been to understand the role of synthetic phonics, nowadays prescribed by government to be used in all primary schools in England, in literacy teaching. Accordingly, throughout the first weeks of my weekly visits to a year 1 class, I focussed my attention on their regular phonics lessons. 
As I continued my weekly visits to the class, I gradually became interested in literacy as it was used throughout the school day, in all lessons. While phonics and ReadWrite lessons (where children practiced reading with the help of short texts linked to the phonics programme) happened daily, they were short, no more than 30 minutes long. Children did a lot more throughout the school day that involved literacy. In their maths, science, art or religious education lessons, they read, listened, wrote, drew or dramatized. As I noticed the important role of literacy throughout the school day, I also began to pay greater attention to literacy practices related to the Catholic faith, such as worshipping, school mass, prayers and singing. As these activities engaged children with written texts, I began to examine the contribution these may make to the children's growing literacy ability.

The aim of this paper is to examine whether and how the Catholic literacy practices that were part of worshiping, singing or listening to Bible stories supported children's literacy learning. To address this aim, in the following I first discuss the background to my study, the theory that underpins it and previous research which informs it. I then present three examples of Catholic literacy practices that I observed in the school. My discussion of these examples highlights in what ways these practices can be said to contribute to the children's literacy learning. I conclude with a brief discussion of the wider relevance of these findings while also pointing out the limitations of my ethnography.

\section{Policy and research background}

Current literacy policy for the early years of primary schooling, in England and other English-speaking countries, favours a method called phonics: reading and writing are taught through explicit instruction in letter-sound relationships. Much has been written about phonics and synthetic phonics, the approach used in England, its merits and pitfalls and there is no need to repeat these discussions here (Lewis and Ellis 2006, Ellis 2007). Politicians and the media like to describe phonics as the magic bullet ensuring that all children learn to read and write (Papen 2016). The privileging of phonics is a recent phenomenon in literacy policy though. In the 1970s, a more integrated and cross-curricula approach to literacy was favoured (Cove 2006) . Nowadays many practitioners and researchers remain sceptical of the prescribed emphasis on sound-letter skills. They suggest that phonics needs to be a component in a much wider literacy pedagogy and that children's engagement with meaningful and appealing texts is crucial for literacy pedagogy (Dombey 2014). The new National Curriculum in England, although prescribing details of phonics teaching, also states explicitly that children need to be given opportunities to listen to and talk about a wide range of fiction and non-fiction texts (DfE 2014 11).

The new Curriculum also refers to the role literacy plays across the curriculum in all subjects, by stating that 'Teachers should develop pupils' spoken language, reading, writing and vocabulary as integral aspects of the teaching of every subject' (DfE 2014 11). But there is little detail in the curriculum document on how literacy contributes to subject-specific teaching. About history in year 1 for example the curriculum only states that 'common words and phrases relating to the past' should be taught (DfE 2014 246). How learning about history 
might support children's more general competence in reading and writing is not explained. There is no mention of literacy as a means of communication and interaction throughout the school day, beyond lessons.

\section{Theoretical background: Literacy as social practices and multiliteracies}

Current policy on literacy in schools is informed by a concept of reading and writing as discrete cognitive skills and by what is known as the 'simple view of reading' (Harrison 2010). In this paper, however, I understand literacy to be a social practice (see Street 1993 , Gee 2012, Barton 2012). The core idea is that literacy is best understood not as decontextualized ability but as a motivated activity: as something people do in particular contexts and situations, pursuing specific intentions. What people do with literacy is shaped by the values and ideas that they hold about that activity. The texts which are part of these literacy practices are engaged with because of the knowledge and ideas they carry and the purposes they allow users to fulfil. Researchers refer to literacy in plural, as practices, because reading and writing as happening in specific situations takes many different forms and is embedded in a variety of activities and purposes (Barton and Hamilton 2012).

A theory of literacy as social practice implies an understanding of learning that locates cognitive change within the context of social interaction and the child's participation in practices 'guided' by more experienced others (Rogoff 2003). Lave and Wenger's (1991) concept of 'situated learning' emphasizes the importance of the learner participating in meaningful practices (in my case practices that involve literacy) which offer them opportunities to experience and absorb new understandings and ideas.

The second important concept I draw on in this paper is multimodality. This refers to the use of more than one resource for meaning-making in the context of communication (Kress and Jewitt 2003). In schools, traditionally, literacy teaching is focussed on 'print literacies', reading and writing letters (McKee and Heydon 2015 229). But most texts children engage with, in and outside school, use different modes: they combine writing with images and they make use of visual aspects of writing such as letter size or page layout to communicate the author's intended meaning. Other modes are sound, gesture or movement. Many of the texts children are asked to use in schools, for example worksheets or phonics cards, are multimodal. A pedagogy of multimodality, also referred to as 'multiliteracies' (Kalantzis and Cope 2012) presumes that in today's world, children need to learn to communicate and make meaning by drawing on a broad range of modes, as texts prominently draw on several semiotic resources, written language being just one of these (Maine 2013). This approach differs from the current policy focus on phonic knowledge and other languagebased skills (e.g. grammar). The English curriculum for year 1 (five to six-year-olds) does not comment on the role of different modes in communication. Multimodality is important for my study because, as I will show below, the religious literacy practices I found in the school were multimodal. 


\section{Religious literacy and religious literacy practices}

Religious literacy is often defined in relation to a person's ability to act on their religious understandings and beliefs, displaying ideas and behaviours that are deemed to be in accordance with their faith (Rumsey 2010, Wright 1993). Departing from this, the understanding of religious literacy that I draw on in this paper is informed by a social practices perspective on reading and writing. Kapitzke's (1995) view is particularly helpful for my study. She defines religious literacies as 'goal-directed sequences of activities organised around sets of beliefs, values, symbols, artefacts, narratives and rituals. These constitute regimes of rationality in which theological truths and justifications are produced about issues of physical and moral concern' (Kapitzke 1995 3). Kapitzke's definition aligns with my understanding of literacy as culture-specific, goal-oriented and value-framed practices. The choice of the plural is deliberate here and reflected in my use, throughout this paper, of the phrase 'religious literacy practices' to refer to what Kapitzke describes in her definition. It is important to note though that in my study I did not examine these religious literacy practices in the way they shaped the children's practices as believers. Instead, I focussed on how religious literacy practices can support children's engagement with reading and writing.

Although not explicitly mentioning multiliteracies, Kapitzke's above definition suggests that she understands religious literacies as involving combinations of different modes of communication. Multimodality was a common feature of the religious literacy practices that I witnessed in the school and which I discuss in this paper. It is important not to forget though that sacred texts such as the Bible or the Qur'an play a decisive role in guiding a person's practice and behaviour as a believer (Rumsey 2010, Rosowsky 2008).

Kaptizke's notion of religious literacy practices is similar to what Gregory et al. (2013 31), who also understand literacy as a social practice, call 'faith literacy practices'. Faith literacy practices are a synonym for what Rosowsky $(2008,2015)$ calls 'liturgical literacies'. Gregory and her colleagues discuss in particular the importance of 'performances' of sacred texts as essential to such practices. Performance means a form of 'acting out' of hymns or prayers which unlike the idea of performance as achievement that is prevalent in schools, refers to a bodily and sensual experiencing of texts. An important question though is what kind of learning such performances afford (Gregory et al. 2013 ).

The understanding of religious practices set out in the previous paragraphs is based on studies of reading and writing in different faith communities. Such communities have their own sets of literacy practices. In this paper, I am concerned with reading and writing that is part of the Catholic religion and I refer to this simply as Catholic literacy practices.

\section{Studies of religious literacy practices and their roles in school}

The links between religion, literacy and education have been extensively studied from a historical perspective (Graff 1987, Luke 1989, Skerrett and Bomer 2011). From these and other studies we know that Christianity has played an important role in literacy education. The Bible and other devotional texts were important curriculum materials (Skerrett 2013). In 
Catholic schools in early modern Germany for example Latin prayers, hymns and other ritual texts were used for teaching reading (Rutz 2012).

There is less research on contemporary contexts. Few studies have been published on the contribution religious literacy practices can make to literacy teaching in the early years of primary schooling. Researchers who are interested in religious practices focus on family, community and faith contexts although they make links with educational settings (Heath 1983, Street 1993, Kapitzke 1995). Gregory et al.'s (2013) study of four faith communities in the UK shows that taking part in religious practices outside schools offers children opportunities for literacy learning. Volk and de Acosta's study of Latino kindergarten children in the US offers similar insights into how literacy learning is supported by children engaging in their family's religious literacy practices. For one mother, Bible reading with her daughter was 'a reading lesson as well as a religious event' (Volk and de Acosta 2001 206).

Recent research on religious literacy practices in secondary schools offers two important insights. Firstly, Skerrett's work (2013) has shown that students' knowledge of religious literacy practices can support their understanding of secular texts and can help them when writing (secular) academic genres. Secondly, research by LeBlanc and Rosowsky suggests that engagement with religious literacy practices can differ from the reading and comprehension practices that are commonly valued in schools. LeBlanc shows that in the Catholic high school he worked in, during Mass for example, pupils were asked to read texts to the congregation. For the teachers, it was important that they read loudly and clearly, with the correct intonation, but the meanings of the prayers were not discussed (LeBlanc 2015). Rosowsky's (2008) study of literacy in a Mosque schools confirms that in religious contexts, reading may not be focussed on comprehension, but on decoding, chanting and learning by heart.

As I became aware of the dearth of studies on the role of religious literacy practices in the context of literacy teaching in schools, I tried to find out whether religious practices have been studied by scholars interested in what is known as content area literacy, also referred to as 'literacy across the curriculum'. But the studies I found are limited to areas such as science, math or history. Ming (2012) for example looks at content-area literacy strategies for art, mathematics, music and physical education. She defines content-area literacy as 'the ability to use listening, speaking, reading, writing and viewing to gain information within a specific discipline' (Ming 2012 214). This is also captured by the idea of 'literacy across the curriculum' which gives rise to interventions to improve reading or writing in the context of specific subjects (Knipper and Duggan 2006, Bentham, Davies, and Galbraith 2016).

Literacy across the curriculum considers how literacy teaching can support subject teaching. Ming, however, suggests that teachers should develop content-area literacy because in doing so, they do not only enhance their pupils' content/subject knowledge, but also their 'language arts abilities' (2012 214). Language arts, as described by Ming, are similar to what the English national curriculum refers to as literacy. My study takes a similar perspective: I am interested in how reading and writing that takes place in the context of religious practices may contribute to children's general literacy abilities. 


\section{The study and its methods}

The data I present in this paper is part of a wider study of literacy teaching and learning in a primary school conducted from October 2013 to June 2014. I spent one day a week in a year 1 class of a Catholic primary school. The school, which I call St Hilda, is located in a city of the North of England. It is a small school with one class per year. Its percentage of children receiving free school meals is below the national average. The school is rated outstanding by the national school inspection service and regularly performs very highly in the national assessments (SATs).

My study can best be described as a classroom ethnography. Although I took part in school assemblies, parent evenings and Mass, my focus was on the year 1 class and their lessons. There were 30 children in the class, five and six years old, one teacher and two teaching assistants. When I began my observations, only two of the children were bilingual. After Easter, two children whose families had recently moved to England joined the class. In accordance with government policy, St Hilda was open to children who are not Catholic. From talking to the children and their teacher I know though that a significant number of them came from Catholic families.

The choice of ethnography is motivated by my understanding of literacy as social practice and by my belief in ethnography as a specific research paradigm, not just a research method or bundle of methods. To begin with the first, literacy practices, as explained above, take their meaning from the context they are part of. Accordingly, they have to be studied in context. Learning too is situated and social. Participant observations allow researchers to study phenomena such as literacy learning in the contexts and situations where they happen.

As a research paradigm, ethnography is grounded in specific ontological premises. Here, my position is informed by understandings of language (and thus, literacy) developed in US based linguistic anthropology (Hymes 1974) and its UK-based equivalent, linguistic ethnography (Creese and Coupland 2015). In this tradition, ethnography is considered to be a form of 'deep theorising' (Blommaert and Jie 2010) based on the premise that the 'object' of our work, language, is inseparable from culture and can only be understood as 'real world' practice, situated in and shaped by different actors operating in specific social and cultural contexts. With regards to epistemology this means that in order to understand literacy learning and teaching, I had to engage with the 'real life' contexts where such learning and teaching takes place and that, in doing so, I had to try to understand the experience of those taking part in this context. My focus on real life contexts and the assumption of complexity (Lillis 2008) opens up a perspective on literacy learning that provides an alternative to the simplifying accounts set out in policy documents and curriculum guides.

In practical terms, my ethnography involved participation and observation. At the beginning of my work, the teacher, Ms L introduced me to the class - I call it Tulip class - as a researcher who wants to understand how children learn to read and write. Rather than sitting at the back as a detached observer, I preferred to be directly involved, sitting with the children and helping in any way suggested by the teacher or teaching assistants. In that way, 
my role in the lessons was similar to that of a parent helper, a position the children were familiar with. While my participation in the lessons meant that note taking often happened in brief moments between activities or during break time, the close interaction with the children allowed me to understand better what literacy learning was like for them than had I stayed at the back of the class. I also developed close relations with the teacher and teaching assistants and the many conversations I had with them throughout my stay greatly benefitted my study.

As explained earlier, my study had originally focussed on understanding the role of phonics in literacy teaching. Once I started spending time in Tulip, however, I soon became aware of the role of literacy in science, history and religious education (RE). Every day, the children took part in religious activities. Singing was a daily practice in Tulip and the class prayed every day, before lunch and at the end of the school day. Once a week, they joined in worship with the year 2 group. They regularly attended Mass. School assemblies, every Monday and Friday, included prayers and hymns. All these activities involved language and often written language.

The data I draw on in this paper consists of fieldnotes from my visits to the class, notes from many informal conversations with the teachers, teaching assistants and children and documents collected during my time in school (e.g. exercise sheets). My fieldnotes cover all lessons and activities I took part in during the school day. I did not take notes during religious events, as I considered this to be disrespectful of the situation. Instead I jotted down quick notes after the worship or when returning to class after Mass. I often used the lunch break for writing down observations. Fieldnotes, as any ethnographer knows, are shaped by what the researcher has set out to explore. As I wanted to understand how literacy was taught, my fieldnotes, in particular in the first weeks and months, focussed on the teacher and teaching assistants and how they conducted the lessons. This does not mean that I did not pay attention to the children. But it is fair to say that in particular when trying to understand the teachers' work my ability to at the same time capture children's reactions to the lessons was limited.

I analysed my data using an inductive content-based approach. For the purpose of this paper I selectively examined all fieldnotes covering religious activities and religious reading and writing practices. I also compared these with the phonics and ReadWrite sessions that I had written about. The main research aim framing this analysis was my desire to understand whether and how such practices contributed to the children's growing ability to read and write. My repeated readings of these fieldnotes resulted in the identification of codes and subcodes (such as 'Catholic literacy practices', with 'hymns' a sub-code or 'performance and bodily engagement with text' as another code). This process was also informed by my reading of other studies. For example, when I read about an apprehensive approach to text (see below) I began to consider to what extent this could be seen in my data.

\section{Religious literacy practices in a primary school: three examples}

In the following, I present three activities, taken from my observations, to examine the presence of (Catholic) religious literacy practices in St. Hilda. The three examples include the regular worship, practicing hymns and the children learning about Noah's ark.

\section{The weekly worship}


Every Tuesday morning, Tulip class joined the year 2 class for a worship led by one of the teachers. The worship took place in one of the classrooms, the children sitting on the carpet around a little altar, with a statue of Mary and a candle placed in its middle.

The worship usually began with the teacher reading a short religious text. In November, over several weeks, the children had talked about saints during their worship. On 17.11., the teacher, Ms L began the worship by telling the children about St. Michael, the archangel, who, she explained, 'helps people when something is bothering them'. Ms L then read a story about St. Hilda, the saint after which their school was named. While reading, the teacher explained some of the words in the story. For example, she talked about the word 'vision', making sure that the children would understand what this means. After her reading she asked the children questions about the content of the story. For example, she asked what the message was that Mary gave to St. Hilda (Mary had appeared to St Hilda as a vision). The children listened quietly while Ms L was reading. There was no shortage of raised hands when she asked a question. During worship, the atmosphere in the classroom despite being somewhat cramped (year 1 and 2 having to share one classroom's carpet space) was always quiet and with few exemptions, the children listened carefully and concentrated on the teacher guiding the worship.

The worship continued with a prayer, the Hail Mary, which the children were already familiar with and could say by heart. But the teacher also commented on the prayer's meaning, explaining how it was linked to the story about St Hilda that they had just discussed. It is Mary, who the prayer is devoted to, who had appeared to St. Hilda. The worship ended with another song and the teacher telling the children about the new Church year beginning the following Sunday. She invited them and their families to come to Mass on Sunday.

\section{A lesson about Noah's ark}

In December, I observed a morning activity on the story of Noah's ark. On this particular morning, this lesson replaced the ReadWrite session. Using a big book and a slide show, Ms L told the class about Noah's ark. She read the story to them, using the slides, but also pointing to the images in the big book that was placed in front of her. While reading, she used the curser so that the children could follow the words displayed on the slides. From time to time she asked the children questions. For example, she asked why the ark had to be very big and why Noah had to make a plan (there was a slide with a picture of Noah sitting at a desk writing). When they reached the part where the storm began, she asked the children to describe what was happening. She wanted to know how long the storm had lasted. She invited the children to read together from the slide to answer her question. Ms L also asked us to imagine what it must have been like for Noah and his family to be on the ark. She invited us to pay attention to the wind outside. I noticed how all the children went quiet, listening for the wind. She told us about her son who worked on a ship in the North Sea and that he sometimes texted her when there had been a bad storm.

As she carried on reading, Ms L continued to ask questions, about the duration of the storm and the meaning of the dove. She talked about the rainbow, explaining that it was a sign of God's promise that there would be no other flood. She then initiated a discussion about 
promises and their importance, linking this first to the children's own experiences, then returning to Noah. She asked the children who go to Brownies (Girl guiding) if they could remember the promise they make when they meet. One child stood up to say it aloud. Then Ms L asked why God had brought the flood. A boy explained that it was because people had been unkind and horrible to each other. 'Maybe you have sometimes been unkind', Ms L suggested. She invited the children to think about a time when they might have been unkind, adding that it could happen to her, in particular when she was tired. Finally, she lit a candle, asking everybody to close their eyes, to be still for 40 seconds (the flood had lasted 40 days) and to think about a promise they could make to their parents or to somebody else. She distributed pieces of paper for the children to write down their promise.

Throughout this lesson, the children listened attentively to the story and to Ms L's questions. But the discussions she initiated were lively, revealing the children's engagement with the story and its message. Everybody joined in, when she asked us to be still for 40 seconds.

\section{Singing}

Singing was a regular practice in Tulip class and I do not recall a day of classroom observations without the children practising a song. Both religious and secular songs were part of the children's repertoire. While the teacher used singing for a variety of purposes, for example to bring everybody back together after group work or play time, much of the singing happened as part of worship, Mass or assembly. Hymns were practiced and performed. For example, the class would learn a new hymn for the school assembly. In the weeks before Christmas the children had to learn the songs of their Nativity play. During these weeks rehearsing for the Nativity play several times took precedence over phonics and ReadWrite lessons.

The children always enjoyed singing. Everybody joined in and I could see that some children were particularly enthusiastic performers. Singing involves reading, at least until the singer has memorized the lyrics. When Tulip class learned a new song, the teacher displayed these on the interactive whiteboard. Leading the singing with her own voice and guitar or using a recording of the melody, she invited the class to 'sing the words'. This was a collective act of reading and not relying on the individual child's ability to decode the words on the screen. Surrounded by their classmate, a child who could not read a word could listen to the others and pick up any parts they struggled to decode.

Over the weeks and months of my coming to Tulip class, I became acquainted with some of the hymns the children sang regularly. In my fieldnotes, I comment on the lyrics of some of the popular hymns the children performed. 'You have called us by our name', reprinted below, is one of them. When singing, everybody joined in. They all knew the lyrics. I often observed the children singing during play time, practising the hymns they learned. They had memorized the text. Song lyrics, like poems, use repetition and rhyme, no doubt contributing to their appeal and making them easier to remember.

[Figure 1 near hear] 


\section{Discussion: what the three examples tell us about literacy learning in the context of religious literacy practices}

I have chosen the above three examples, because they illustrate how Catholic literacy practices, including those of worship and prayer, can contribute to children's literacy learning.

Looking first at the worship, although it was framed for the children as a religious activity, it had similarities with the regular (non-religious) whole class reading sessions I frequently took part in. Whole class reading happened daily. Usually, the teacher or a teaching assistant would read from a picture book. The children sat on the carpet, in a circle around the adult reader. During worship, the teacher also read to the children. Similar to how she and the teaching assistants conducted whole class reading sessions, during worship Ms L asked questions that were intended to support the children's understanding of the text. That such a written text served as anchor for the children's engagement with knowledge and ideas further highlights that this devotional activity had similarities with literacy pedagogy as used in school and with literacy practices the children were used to from their literacy lessons and other subjects.

The primary purpose of the lesson on Noah's ark was to acquaint the children with this important Bible story. But once again, this activity, although framed as religious practice, was similar to whole class reading lessons. The children sat on the carpet, from where they could see the slides as well as the book the teacher used. The children could draw on words and visual images to support their understanding of the story. During the reading, as Ms L pointed to specific words on the slides or in the book, she invited the children to read on their own. She asked questions which are comparable to the comprehension questions she and the teaching assistants always included in whole class reading activities. But Ms L also invited the children to comprehend using sensual experience and imagination. She made us sit still and listen to the wind outside; asking us to imagine what it might be like to be on an ark during a storm. She used her son's work to relate the experience to a modern context closer to the children's own worlds. Later in the lesson, talking about God's promise, she again supported comprehension by relating the content of the story to the children's own experience (girl guiding), showing the relevance of promises in their own lives.

Singing, my third example, is easily recognised as a literacy practice. Singing is a multimodal practice. In Tulip class, it often included reading, but relied essentially on the words being sung, thus on sound and melody, and in many cases, on movement and performance. Opportunities for learning words, as they are printed, arose from engagement in these multimodal 'ensembles' (McKee and Heydon 2015). Research about singing and literacy suggests that songs help children recognize words and thus to develop their vocabulary (Winters and Griffin 2014). Reading and performing poetry, Cremin (2009 122) proposes, allows children to 'engage with verse, feel its rhythms and connect to the content'. Songs have similar affordances. It is reasonable to suggest that the music and the act of singing further enhance the 'connection' with the text that Cremin talks about. Such connection with and experience of a hymn gives it meaning independent of the child necessarily understanding every word of the text. I make this point here because looking at the above 
reprinted hymn, we can see that it includes some words (unity, establish, convey) that are unlikely to be part of the children's every day vocabulary. When the children in Tulip class 'sung' the words of a new song, what they did is similar to 'choral reading'. This form of reading aloud, in unison, led by the teacher has been found to support fluency and its performative aspect motivates children (Paige 2011).

What can we conclude from the above three examples in terms of the contribution they make to children's literacy learning? To begin with, it is important to acknowledge Ms L's views. When discussing my ideas with her, her reaction - surprise - indicated that for her, worship, hymn practices and other religious activities, primarily serve devotional purposes. She did not conceive of these as supporting her literacy teaching. When I put it to her that these activities could be seen to provide opportunities for literacy learning, she did, however, agree. Ms L explained that phonics and ReadWrite were effective tools for literacy teaching, but that it was crucial to embed these skills focused lessons in a wider literacy curriculum. She agreed with me that reading Bible texts or practicing hymns contribute to such a curriculum.

But how did the kind of religious practices I described in this paper support the children's literacy learning? In the first instance, singing, prayers, worship and Mass contributed to literacy learning because they afforded exposure to and experience of different text types and different forms of language. In his keynote speech delivered at UKLA's international conference in 2014, children's book author Michel Rosen referred to the religious practices in the primary school he attended as a child as 'text-heavy' and offering 'textual variety'. In St. Hilda, the texts that were part of religious practices can be seen to serve as curriculum materials, offering alternatives and variation to the structured readers and the reading and writing tasks that were used in phonics and ReadWrite sessions. In the daily phonics sessions for example, teaching focussed on phonemes, graphemes and words and also involved the children in memorizing phrases and making short sentences. But no extended text was involved. In the ReadWrite sessions, the children primarily used the decodable readers included in the phonics programme the school used. These included both fiction and nonfiction text. However, in particular at the beginning of the school year, these were very short texts, restricted in their content and, as I noted elsewhere(Papen 2016), of limited appeal to the children.

During worship or when practicing hymns, the children engaged with texts that were too difficult for them to decode themselves and containing ideas they would not easily be able to make sense of on their own. Exposure to such texts makes an important contribution to literacy learning (Bower and Barrett 2014). Access to meaning was supported by multimodality: a child could draw on the images that accompanied the text or could listen to the words sung by others. That Catholic literacy practices are multimodal makes them similar to many other non-school literacy practices the children were likely to engage with at home and in their families. In contrast to the focus on written language in current literacy policy, the Catholic literacy practices I discussed in this paper supported children's multimodal meaning making, which is a key aspect of what contemporary literacy ability is about (Kalantzis and Cope 2012). In addition to drawing on visuals, voice and music, this also included inferring meaning of words from context. 
In the above practices an individual child's lack of reading and writing ability was no hindrance to their participation in the event as this was collaborative and supported by more experienced others. That all the children joined in when we sang, prayed or practiced for the nativity, was evident for me as observer and participant in the activity. Participation and a sense of community were a strong ethos in St Hilda, a point I often reflected on in my fieldnotes and which was particularly visible in the way the teacher and teaching assistants supported the children's sense of learning together, in all lessons (Papen 2016). One of the teaching assistants spoke to me about the sense of 'belonging' that singing, praying and other religious practices engendered. It is therefore reasonable to assume that the collaborative nature of the practices that I discussed in this paper offered children experiences of literacy that are motivating and engaging and thus contributed to their learning.

To what extent though do religious literacy practices afford not just decoding, memorizing and participation but comprehension? Are practices such as praying and singing limited to rote learning or do the children understand what they sing or chant in their prayers? My earlier examples show that the teacher was certainly concerned with the children's understanding of important Bible content. But what about prayers such as the Hail Mary? I do not recall the teacher explaining the words and meaning of the prayer to the children. And while my fieldnotes mention occasional classroom discussions around the meanings of a song, this was not a regular practice I observed. During assembly, hymns were performed but not discussed.

The orientation to text that shapes religious practices has been described as 'apprehensive' rather than based on comprehension and understanding. Baker (1993 98) defines apprehension as a 'socially significant practice of taking up a text and going through the process of actualizing the inscribed words in a temporal sequence'. To 'apprehend' a reading, he explains, means 'coming to grips with what there is to know without necessarily knowing how to subject it to predications, that is, how to adequately comprehend it' (Baker 1993 108). Based on his work in a Catholic high school Le Blanc argues that the 'embodied interaction' with texts during Mass, when they stood in front of their peers, reading a prayer is different from 'denotative understanding' (LeBlanc 2015 257). The young students (Grade 8) in LeBlanc's study 'performed' prayers, but admitted that they did not necessarily understand what they read.

The question this raises is how we define 'comprehension'. Volk and de Acosta (2001) remind us that schools tend to value only certain kinds of literacy, what we know as academic literacies. These require processes of rational thinking and close analysis of texts captured by terms such as 'reading comprehension'. In religious contexts though, other forms of literacy are important, for example repetition, memorization and joint recitation of texts. These practices, Volk and Acosta suggest, may be interpreted to be limited to children saying words without understanding them. The question though is what kind of 'meaning' children may take from these texts even if they do not 'comprehend' all its detail. Gregory et al. (2013) explain that many of the texts in their study are texts that 'protect'. This can also be said about some of the texts the children in St Hilda engaged with, for example the Hail Mary. The sense of protection is 'understandable' without the child being able to comprehend every 
word of the prayer. Furthermore, the meaning of a prayer or hymn does not derive solely from the words it contains, but from the context and event as part of which it is performed. What I take from the above is that in the context of the Catholic literacy practices in St.Hilda, comprehension is not to be seen as a process of logical thinking, but more akin to a practice of being 'empathetically attuned with the meaning of a text' (Baker 1993 133). Rosowsky (2015 178) suggests that 'acting out' or 'performing' of for example a prayer allows for 'more artistic and aesthetic modes of analysis and appreciation'. Furthermore, comprehension is undoubtedly a social act and what an individual child takes from a text such as the Hail Mary cannot be understood without considering that child's wider experiences, at school, at home and in their community (Smith 2010).

\section{Conclusions: religious literacy practices, learning and the limits of ethnography}

In the current policy context, little attention is given to religious literacy practices and the contribution they can make to literacy pedagogy. In England and elsewhere though, a significant number of schools are faith-based. In such schools, children are likely to regularly engage in religious literacy practices and such practices are valued by their school community. There may be reasons then for educators and researchers to pay greater attention to these literacies, as Eakle (2007) has already suggested.

Taking the example of one particular school, in this paper I have shown that the Catholic texts and practices children engage with provide opportunities for literacy learning. The particular contribution these practices make is that they engage children in reading for a purpose, engaging the children actively in experiencing and making sense of written texts. Current educational policies focus strongly on the explicit teaching of skills such as understanding grapheme-phoneme links, spellings or punctuation, with meaning and engagement with ideas is relegated to the margins.

The Catholic literacy practices the children in Tulip class engaged with showcased for them that reading and comprehension can take forms other than what is commonly associated with academic literacies with their focus on rational thinking, correct decoding and close textual analysis. Religious literacy practices afforded more emotional and embodied forms of meaning making. Because religious literacy practices are collaborative activities, even the weaker readers could take part without having to fear teacher criticism. This allowed for learning through participation and joint practice. That written texts invite for meaning making in broad terms, including emotional engagement and apprehension, is not unique to religious contexts though. There is an argument to be made here for schools to acknowledge and encourage different approaches to understanding, in the context of for example children's engagement with stories and fiction. Current policy and assessment regimes neglect such engagement, focussing instead on measurable and testable skills such as phonic knowledge.

My study is, however, not without limitations. As described earlier, as a participant observer in a busy classroom, my attention was divided between the teachers and the 30 children, not allowing me to gain a deeper understanding of how individual children engaged with the religious literacy practices that I described in this paper. To do this, I would have had to focus 
my attention on a small group, spending time shadowing individual children and engaging them in conversations about their literacy learning. To gain a deeper understand of what specific children learned from engaging in Catholic literacy practices, I would have to extend my ethnography to their homes and families, to capture the interface between home, school, and - possibly - church in a child's literacy learning. A more long term approach would be required.

Despite these limitations, my study invites us to continue to reflect on how, in the current education system, reading and writing is easily narrowed to specific practices, fitting the dominant understanding of literacy. This policy risks neglecting the variety of literacy practices, including those related to (in my case) the Catholic religion, children engage with in school and at home. The religious literacy practices discussed here are unique insofar as their content is concerned (the specific ideas children are exposed to). In other ways though, religious literacy practices are similar to many other forms of literacy, valued in schools and beyond. This includes multimodal forms of communication, required for example in science lessons, but absent from the learning goals of the primary literacy curriculum. This shows that religious literacy practices are but one example of the variety of literacy practices that children in schools should be encouraged to engage with and learn from. Such practices deserve our attention, because they are an essential and valued means of communication, social interaction and knowledge creation, thus contributing to children's experiences of literacy, in and beyond educational settings.

Acknowledgement: I would like to thank the school, the teachers and teaching assistants as well as the children for supporting my research and sharing their practices and ideas with me. I would also like to thank my colleague Mary Hamilton and the two anonymous reviewers for their very helpful comments on earlier versions of this paper.

\section{References}

Baker, James N. 1993. "The presence of the name: reading scripture in an Indonesian village." In The ethnography of reading, edited by Jonathan Boyarin, 98-139. Berkeley: University of California Press.

Barton, David. 2012. Literacy : an introduction to the ecology of written language. 2nd ed. Oxford, UK ; Cambridge, Mass.: Blackwell.

Barton, David, and Mary Hamilton. 2012. Local literacies : reading and writing in one community, Routledge linguistics classics. London; New York: Routledge.

Bentham, Jo, Peter Davies, and David Galbraith. 2016. "Using a "Literacy across the curriculum" intervention using self-regulation." Educational Review 68 (1):71-81. doi: 10.1080/00131911.2015.1058751.

Blommaert, Jan, and Dong Jie. 2010. Ethnographic Fieldwork : A Beginner's Guide: Multilingual Matters.

Bower, Virginia, and Susan Barrett. 2014. "Rhythm, rhyme and repetition." In Developing early literacy 0 to 8, edited by Virginia Bower, 118-135. Los Angeles: Sage.

Cove, Moya. 2006. "Sounds familiar: the history of phonics teaching." In Phonics. Practice, research and policy, edited by Maureen and Ellis Lewis, Sue, 105-113. London: Sage: Sage and UKLA. 
Creese, Angela, and Fiona Coupland. 2015. Linguistic Ethnography: Collecting, Analysing and Presenting Data. London: Sage.

Cremin, Teresa. 2009. Teaching English creatively. Abington: Routledge.

DfE. 2014. The National Curriculum in England. Framework document. edited by Department for Education.

Dombey, Henrietta. 2014. "Flying blind: government policy on the teaching of reading in England and research on effective literacy education." In Whose knowledge counts in government literacy policies?, edited by Kenneth S. Goodman, Robert C. Calfee and Kenneth S. Goodman, 67-79. New York: Routledge.

Eakle, A. Jonathan. 2007. "Literacy spaces of a christian faith-based school." Reading Research Quarterly 42 (4):472-510. doi: 10.1598/RRQ.42.4.3.

Ellis, Sue. 2007. "Policy and research: Lessons from the Clackmannanshire Synthetic Phonics Initiative." Journal of Early Childhood Literacy 7 (3):281-297. doi: 10.1177/1468798407083660.

Gee, James Paul. 2012. "Social linguistics and literacies ideology in discourses." In. Abingdon, Oxon ; New York: Routledge. http://ezproxy.lancs.ac.uk/login?url=http://lib. myilibrary.com?id=343505.

Graff, Harvey J. 1987. The legacies of literacy : continuities and contradictions in Western society and culture. Bloomington: Indiana University Press.

Gregory, Eve, Halimun Choudhury, Arani Ilankuberan, Amoafi Kwapong, and Malgorzata Woodham. 2013. Practice, performance and perfection: learning sacred texts in four faith communities in London. In International Journal of the Sociology of Language.

Harrison, Colin. 2010. "Why do policy-makers find the 'simple view of reading' so attractive and why do I find it so morally repugnant?" In Interdisciplinary perspectives on learning to read, edited by Kathy Hall, Usha Goswami, Colin Harrison, Sue Ellis and Janet Soler, 207-219. London: Routledge.

Heath, Shirley Brice. 1983. Ways with words : language, life, and work in communities and classrooms. Cambridge [Cambridgeshire] ; New York: Cambridge University Press.

Hymes, Dell H. 1974. Foundations in sociolinguistics: an ethnographic approach. . Philadelphia: University of Philadelphia Press.

Kalantzis, Mary, and Bill Cope. 2012. Literacies. Cambridge: Cambridge University Press.

Kapitzke, Cushla. 1995. Literacy and religion: the textual practices of Seventh-Day-Adventism. Philadelphia: John Benjamins.

Knipper, Kathy J., and Timothy J. Duggan. 2006. "Writing to Learn Across the Curriculum: Tools for Comprehension in Content Area Classes." The Reading Teacher 59 (5):462-470. doi: 10.1598/RT.59.5.5.

Kress, Gunther, and Carey Jewitt. 2003. "Introduction." In Multimodal literacy, edited by Carey Jewitt and Gunther Kress, 1-18. New York: Peter Lang.

Lave, Jean, and Etienne Wenger. 1991. Situated learning: legitimate peripheral participation. Cambridge: Cambridge University Press.

LeBlanc, Robert Jean. 2015. "Performance and Apprehension of the Mass in an Urban Catholic School: Strategy, Liturgy, Capital." Written Communication 32 (3):254-285. doi: 10.1177/0741088315587904.

Lewis, Maureen, and Sue Ellis. 2006. Phonics practice, research and policy. Thousand Oaks, Calif.: Sage.

Lillis, Theresa. 2008. "Ethnography as Method, Methodology, and "Deep Theorizing": Closing the Gap Between Text and Context in Academic Writing Research." Written Communication 25 (3):353-388. doi: 10.1177/0741088308319229.

Luke, Carmen. 1989. Pedagogy, Printing and Protestantism: The Discourse on Childhood. Albany, NY: SUNY Press. 
Maine, Fiona. 2013. "How children talk together to make meaning from texts: a dialogic perspective on reading comprehension strategies." Literacy 47 (3):150-156. doi: 10.1111/lit.12010.

McKee, Lori L, and Rachel M Heydon. 2015. "Orchestrating literacies: Print literacy learning opportunities within multimodal intergenerational ensembles." Journal of Early Childhood Literacy 15 (2):227-255. doi: 10.1177/1468798414533562.

Ming, Kavin. 2012. "10 Content-Area Literacy Strategies for Art, Mathematics, Music, and Physical Education." The Clearing House: A Journal of Educational Strategies, Issues and Ideas 85 (6):213-220. doi: 10.1080/00098655.2012.691568.

Paige, David. 2011. "'That sounded good!" Using whole class choral reading to improve fluency." The Reading Teacher 64:435-438.

Papen, U. 2016. Literacy and education: policy, practice and public opinion. London: Routledge.

Rogoff, Barbara. 2003. The cultural nature of human development. Oxford: Oxford University Press.

Rosowsky, Andrey. 2008. Heavenly readings: liturgical literacy in a multilingual context. Bristol: Multilingual Matters.

Rosowsky, Andrey. 2015. "Faith literacies." In The Routledge Handbook of Literacy Studies, edited by K. Pahl and J. Rowsell. London: Routledge.

Rumsey, Suzanne Kesler. 2010. "Faith in action: heritage literacy as a synchronisation of belief, word and deed." Literacy 44 (3):137-143. doi: 10.1111/j.1741-4369.2010.00561.x.

Rutz, Andreas. 2012. "Elementary education and the practices of literacy in Catholic girls' schools in early modern Germany." Paedagogica Historica 48 (2):283-298. doi: 10.1080/00309230.2011.603344.

Skerrett, A., and R. Bomer. 2011. "Borderzones in Adolescents' Literacy Practices: Connecting Out-ofSchool Literacies to the Reading Curriculum." Urban Education 46 (6):1256-1279. doi: $10.1177 / 0042085911398920$.

Skerrett, Allison. 2013. "Religious Literacies in a Secular Literacy Classroom." Reading Research Quarterly 49 (2):233-250. doi: 10.1002/rrq.65.

Smith, Vivienne. 2010. "Comprehension as a social act: text, context and readers." In Interdisciplinary perspectives on learning to read, edited by Kathy Hall, Usha Goswami, Colin Harrison, Sue Ellis and Janet Soler, 61-74. London: Routledge.

Street, Brian V. 1993. "Introduction: the new literacy studies." In Cross-cultural approaches to literacy, edited by Brian V. Street, 1-23. Cambridge: Cambridge University Press.

Volk, Dinah, and Martha de Acosta. 2001. "'Many Differing Ladders, Many Ways to Climb...': Literacy Events in the Bilingual Classroom, Homes, and Community of Three Puerto Rican Kindergartners." Journal of Early Childhood Literacy 1 (2):193-224. doi: 10.1177/14687984010012004.

Winters, Karl-Lynn, and Shelley M. Griffin. 2014. "Singing is a celebration of language: using music to enhance young children's vocabularies." Langage and Literacy 16 (3):78-91.

Wright, Andrew. 1993. Religious education in the secondary school: prospects for religous literacy. London: David Fulton.

Figure 1: You have called us by our name.

Acknowledgement: I would like to thank the teacher, teaching assistants and children in Tulip class for sharing their learning and their experiences with me. I would like to thank the journal's anonymous reviewers for their very helpful comments on an earlier version of this paper. 